\title{
THE PROBLEM OF PASSIVE CONSTITUTION IN HUSSERL'S GENETIC PHENOMENOLOGY ${ }^{1,2}$
}

\author{
NATALIA ARTEMENKO \\ PhD in Philosophy, Assistant Professor. \\ St Petersburg State University, Institute of Philosophy. \\ 199034 St Petersburg, Russia. \\ E-mail: n.a.artemenko@gmail.com
}

The problem of passive constitution in Edmund Husserl's phenomenology is worthy of particular attention, since it is passive constitution, rather than active conscious constitution, which can be considered to be one of the focal points of $20^{\text {th }}$ century philosophy. Thematisation of the sphere of passivity is related to resolving the problem of intersubjectivity. The elaboration of the problem of intersubjectivity is not so much a response to an externally cast reproach 'in solipsism' as an internal theme of phenomenology itself. Husserl aspired to establish phenomenological science as being of universal significance to everybody, but in order to make this discipline significant, i.e. in order to make it necessary for everyone else, it was primarily necessary to prove the existence of these other Selves or of the transcendental subjects. I will elaborate on the history of the consideration which Husserl gave to the problem of intersubjectivity, in order to clarify how his attempts to resolve the problem of intersubjectivity, based on the activity of the Self, led to an egocentric model, and in turn how the need to overcome this model led to the thematisation of the genesis of subjectivity, and the detection of passivity as the very basis of such genesis. According to my working hypothesis, it was largely the demand for thematisation of the genesis of the sense of 'the Other' which influenced the modification of the phenomenological method. Finally, I will turn to the concept of primary subjectivity, or Ur-Ich, in order to bring into focus the methodological significance of distinguishing the proto-Self for the substantiation of intersubjectivity, since only in its 'context' does the ultimate level of the foundation of the individual Self appear to be not merely a deeper level of consciousness, or the history of a universal subject, but the absolute subjectivity, as a field of intersubjective interaction in which the individual subject is awakened (individualized) to self-constitution in the world. Only then can we reconsider the constitution of the individual Self as being primarily passive, as being permeated by the primordial passive, independent from the Self, aiming for the co-constitution of the intersubjective world.

1 This research is supported by the RFBR (Russian Foundation for Basic Research) research grant No. 18-01100912 "Phenomenological Concept of the World."

2 The article is written on the basis of the plenary report read at the International 16th Annual Conference of the Nordic Society for Phenomenology "Phenomenology of Solidarity: Community, Practice and Politics" (April 19-21, 2016, Gdańsk, Poland).

(C) NATALIA ARTEMENKO, 2019 
Key words: Phenomenological method, intersubjectivity, passive genesis, passive constitution, the Other, E. Husserl, proto-Self.

\section{ПРОБЛЕМА ПАССИВНОГО КОНСТИТУИРОВАНИЯ В ГЕНЕТИЧЕСКОЙ ФЕНОМЕНОЛОГИИ Э. ГУССЕРЛЯ ${ }^{3,4}$}

\section{НАТАЛЬЯ АРТЕМЕНКО}

Кандидат философских наук, доцент.

Санкт-Петербургский государственный университет, Институт философии. 199034 Санкт-Петербург, Россия.

E-mail: n.a.artemenko@gmail.com

Проблема пассивного конституирования в феноменологии Э. Гуссерля заслуживает отдельного внимания, постольку пассивное конституирование, противопоставляемое активному сознательному конституированию, можно назвать одной из основных тем философии $\mathrm{XX}$ века. Тематизация сферы пассивности связана с решением проблемы интерсубъективности изнутри самой феноменологии, а от этого решения напрямую зависит сам статус её исследования. Разработка проблемы интерсубъективности является для феноменологии не ответом на поставленный извне упрёк «в солипсизме», но внутренней темой самой феноменологии. Гуссерль стремится обосновать всеобщую значимую для всех феноменологическую науку - но чтобы эта наука имела значение, а именно была необходима для всех других, необходимо сначала доказать существование этих других Я или трансцендентальных субъектов. Мы остановимся подробнее на истории рассмотрения проблемы интерсубъективности Гуссерлем с целью прояснить, как попытки решения проблемы интерсубъективности, опирающиеся на активность Я, приводят к эгоцентрической модели, потребность в преодолении которой, в свою очередь, приводит к тематизации генезиса субъективности и обнаружения пассивности как самого основания данного генезиса. Согласно нашей рабочей гипотезе, именно необходимость тематизации генезиса смысла «Другого» во многом повлияла на модификацию феноменологического метода. Мы обратимся к понятию первичной субъективности, или прото-Я, чтобы показать, что выделение прото-Я должно пониматься как имеющее методологическое значение для обоснования интерсубъективности, так как только там предельным уровнем фундирования индивидуального Я оказывается не просто более глубокий уровень сознания или истории универсального субъекта, но абсолютная субъективность, как поле межсубъектного взаимодействия, в котором пробуждается (индивидуализируется) к самоконституированию в мире индивидуальный субъект. Только тогда может быть переосмыслено конституирование индивидуального Я как первично пассивное, как пронизанное изначальной пассивной и независящей от Я направленностью на со-конституирование интерсубъективного мира.

Ключевые слова: Феноменологический метод, интерсубъективность, пассивный генезис, пассивное конституирование, Другой, Э. Гуссерль, прото-Я.

3 Статья написана на основе пленарного доклада, прочитанного на международной научной конференции Северного феноменологического общества «Феноменология солидарности: общество, практика и политика» (19-21 апреля 2018 г., Гданьск, Польша).

4 Исследование проведено в рамках проекта «Феноменологическое понятие мира», поддержанного грантом РФФИ, проект № 18-011-00912. 
The problem of passive constitution in Edmund Husserl's phenomenology is worthy of particular attention, since it is passive constitution, rather than active conscious constitution, which can be considered to be one of the focal points of $20^{\text {th }}$ century philosophy.

The theme of passivity, which is not captured reflexively, but at the same time makes itself evident in the life of consciousness, was variously contemplated within the phenomenological movement. The French phenomenology which sprang from the polemic elaboration of Husserl's ideas dealt with the thematisation of corporeality as an inherently passive sphere. For instance, Merleau-Ponty (Alloa, Bedorf, Grüny \& Klass, 2012, 23-51; Novotny, 2012, 58-65) regards the body neither as merely something constituted, nor as merely an instrument of subjective constitution, but as corporeal existence itself, constituting subjectivity. The body, alive and perceptive, remains at the same time hidden from its own self: it precedes any reflection, but remains unobserved by that reflection. French phenomenologists, taking Husserl's phenomenology as the starting point for their own work, acted as his interpreters. However, the significance of Husserl's research goes far beyond its influence on the emergence of phenomenology in the $20^{\text {th }}$ century: the questions posed by Husserl remain topical issues for philosophical thought to this day. Husserl's phenomenological studies ${ }^{5}$ are currently generating strong interest in the field of cognitive theory, as well as in neurobiology, psychology and psychiatry ${ }^{6}$. For example, the sphere of passivity was examined thoroughly by Thomas Fuchs in his modern phenomenological psychiatry. According to Fuchs, the sphere of the passive unconscious is not merely a psychical phenomenon, nor is it repressed, as was considered by classical psychoanalysis. The sphere of passivity is inseparable from the bodily life of the subject. Moreover, it permeates every conscious activity of the subject through the subject's bodily movements and functions; corporeality represents the fundamental structure of subjectivity. Fuchs criticizes the theory of 'pure subjectivity,' drawing attention to the fact that the genesis of subjectivity is corporeal in nature. It is precisely bodily movements and functions which are responsible for introducing the individual into the intersubjective social world, and for constructing intersubjective interaction.

The background and context of the thematisation of passive synthesis and the sphere of passivity essentially originated in the first and second books of Husserl's

On that subject see (Gallagher, 2012, 320-333).

6 See (Fuchs, 2008; Fuchs, 2010). 
Ideas $^{7}$, and were elaborated further in a later text, Analyses Concerning Passive and Active Synthesis (Husserl, 1966). These works revealed and clearly proved the insufficiency of static description for the study of the passive sphere. Mention should also be made here of the collection Phenomenology of Intersubjectivity ${ }^{8}$, comprising three volumes of texts diligently compiled by Iso Kern, which represent works from various periods relating in some or other way to this issue.

\section{THE RELATIONSHIP \\ BETWEEN THE PROBLEM OF INTERSUBJECTIVITY AND THEMATISATION OF THE PASSIVE SPHERE}

We will begin by referring to the consideration of the problem of intersubjectivity given by Husserl in his "Fifth Cartesian Meditation" (Husserl, 1973a), (remember that the Cartesian Meditations was a series of lectures delivered at the Sorbonne in February 1929, representing a concise presentation of the focal points of Husserl's phenomenological method, and aimed at solving the specific theoretical problem of intersubjectivity), highlighting some aporias, before examining passive genesis as a process of the constitution of subjectivity, with reference to a number of texts written by Husserl in the 1930s.

The problem of passive synthesis is closely linked to the distinction between the static and genetic methods of research, the theme of the lifeworld and corporeality. Thematisation of the sphere of passivity is related to resolving the problem of intersubjectivity. According to our working hypothesis, it was largely the demand for thematisation of the genesis of the sense of 'the Other' which influenced the modification of the phenomenological method. The reconstruction method (by which we primarily mean deconstructive analysis) of genetic phenomenology is meant to reveal the sphere of primary passive constitution, the constitution 'from' which the individual Self originates. Husserl was resolving the problem of intersubjectivity by disclosing the genesis of 'the Self' (as occurring in a pair with 'the Other').

7 Reference is made to the first and second books of Ideas Pertaining to a Pure Phenomenology and to a Phenomenological Philosophy (Husserl, 1950; 1952); further referred to as Ideas. First Book (Husserl, 1950) and Ideas. Second Book (Husserl, 1952).

8 Reference is made to three volumes on Phenomenology of Intersubjectivity which comprise texts on the problem of intersubjectivity; further referred to as Phenomenology of Intersubjectivity. First Book (Husserl, 1973b), Phenomenology of Intersubjectivity. Second Book (Husserl, 1973c), Phenomenology of Intersubjectivity. Third Book (Husserl, 1973d). 
The importance of resolving the problem of intersubjectivity cannot be overestimated, since phenomenology, in its desire to be a science, i.e. intersubjective knowledge, claims universal apodictic self-evidence, which can be reproduced at any time and by any subject, and, therefore, the very status of its research depends on resolving the problem of intersubjectivity within phenomenology itself. The questions arising in relation to the problem of intersubjectivity are as follows: how to define the status of veracity of the cogito, the status of experience (as an act of consciousness and as that of which one becomes objectively aware during such acts) and, consequently, how can the status of that which I have reduced to veracity, that which was discovered in the course of intentional self-interpretation, be defined? Can my authentic experience be considered universally significant, or can it only hold the status of significance for me alone? For phenomenology, the elaboration of the problem of intersubjectivity is not so much a response to an externally cast reproach 'in solipsism' as an internal theme of phenomenology itself. Husserl aspired to establish phenomenological science as being of universal significance to everybody, but in order to make this discipline significant, i.e. in order to make it necessary for everyone else, it was primarily necessary to prove the existence of these other Selves or of the transcendental subjects.

However, the construction of intersubjectivity makes sense only if one's own selfhood is present. The theory of intersubjectivity cannot be constructed on the basis of a formal, impersonal, universal consciousness which, by virtue of its universal nature, is the only one of its kind. In this respect, subjectivity has been given a new meaning: in the 1920s there was an emerging tendency for the individual Self to become 'personal,' possessing its own genesis and its own personal transcendental history; in the 1930s, this was followed by the thematisation of the 'lifeworld' (understood as the intrinsic horizon of an entity's intelligibility, but not as the world in its natural attitude) and of primary passive constitution. The fact of phenomenology resorting to thematisation of the 'lifeworld' is a manifestation of the tendency (tracing from Ideas to Cartesian Meditations) of the transition from the impersonal universality of consciousness to one's own Self. This shift represented a response to the internal problems of the phenomenological method. It was related to the need to resolve the problem of intersubjectivity, which was defined in Cartesian Meditations as the problem of the experience of the Other. Finding the solution to this problem was essential for phenomenology in order for it to be regarded as intersubjective knowledge. 
Thus, the Ego must become 'my own,' and yet the Ego of the period of Cartesian Meditations is no longer the universal Ego of Ideas. First Book (the empty pole). But the fact of the Ego becoming personal (concrete) in no way implies its psychologization: as always, we remain within the bounds of the phenomenological reduction and the consequent forfeiture of the significance of belief in the empirical Self in the psychological sense. Here we are referring to the fact that the shift in the nature of phenomenological research from static to genetic provides us with the opportunity to reveal the genesis of the individual Self, which is essential for resolving the problem of intersubjectivity. Even though the project of transcendental phenomenology initially implied only the disclosure of consciousness as the constituting factor, it later revealed the need to uncover the passive genesis of consciousness itself. Husserl gave the following comments on the link between the transformation of the phenomenological method and the need to resolve the problem of intersubjectivity in his First Philosophy:

For me, I have to confess, the first cognition of phenomenological reduction was limited. [...] For years I did not see a way to transform it into an intersubjective one. But finally, a way was discovered, which is crucial for the possibility of complete transcendental phenomenology and, at a higher level, transcendental philosophy. (my translation. - N.A. $)^{9}$

In the 1920s, while attempting to solve the problem of intersubjectivity, Husserl turned his mind to consideration of the genesis of the individual monadic Self.

The phenomenological-eidetic reduction places me on the ground of a possible monad in general, but not on the ground of an individual identically conceivable [monad], [which is necessary] under the requirement to describe an individual identity according to its capabilities and necessities. [...] The phenomenological study which I can describe <as> static is the one which investigates the correlations between constitutive consciousness and constituted objectivity and entirely excludes genetic problems. [...] Finally, we identify the phenomenology of the monadic individuality, which means the phenomenology of the coherent genesis, in whose unity the monad grows, and in whose unity the monad it that which it becomes. (my translation. - N.A. $)^{10}$

9 „Für mich selbst war, wie ich gestehe, die erste Erkenntnis der phänomenologischen Reduktion eine beschränkte. [...] Jahrelang sah ich keine Möglichkeit, sie zu einer intersubjektiven zu gestalten. Aber schließlich eröffnete sich ein Weg, der für die Ermöglichung einer vollen transzendentalen Phänomenologie und - in höherer Stufe - einer Transzendentalphilosophie von entscheidender Bedeutung ist." (Husserl, 1959, 174).

10 „Die phänomenologisch-eidetische Reduktion stellt mich auf den Boden einer möglichen Monade überhaupt, aber nicht gerade einer individuell identisch gedachten und unter der Forderung, die individuelle Identität nach ihren Möglichkeiten und Notwendigkeiten zu umschreiben. [...] < Als > statisch kann ich wohl phänomenologische Forschungen bezeichnen, die den Korrelationen zwischen konstituierendem Bewusstsein und 
During this period, Husserl was endeavouring to resolve the problem of intersubjectivity through structuring monadology, going from an individual monad to a community of monads. However, since the individual Self as a monad and its genesis were still linked by Husserl to the activity of the Self, structuring intersubjectivity on such a basis proved to be highly problematic.

A person, as the 'individuality' of a subjectivity, as a monad, is related to the sphere of specific activity in the form of the Ego cogito. In the manifolds of this cogito, the one and same Ego, as an individuality, unfolds, develops and transforms itself. (my translation. - N.A. $)^{11}$

Therefore, the correlation of activity and passivity came to be reconsidered in the course of the elaboration of the problem of intersubjectivity. In this way, the study of the genesis of the individual monad opened the way to the thematisation of primary passivity, since only if the individual Self, along with all its own activities, has its own genesis, and hence its own beginning, its own transcendental birth, can passivity be understood as primary in relation to the activity of the Self. Only through the individual Self being considered as having his own genesis can we refer to primary passive constitution.

Let us elaborate on the history of the consideration which Husserl gave to the problem of intersubjectivity, in order to clarify how his attempts to resolve the problem of intersubjectivity, based on the activity of the Self, led to an egocentric model, and in turn how the need to overcome this model led to the thematisation of the genesis of subjectivity, and the detection of passivity as the very basis of such genesis.

Thus, the understanding of constitution as an activity of the Self makes constitution of the experience of 'the Other' as the actual Other impossible. For instance, we find the egocentric theory of intersubjectivity in the studies on intersubjectivity from the period prior to the Cartesian Meditations (Phenomenology

konstituierter Gegenständlichkeit nachgehen und genetische Probleme überhaupt ausschliesse. [...] Endlich haben wir die Phänomenologie der monadischen Individualität, darin beschlossen die Phänomenologie einer zusammenhängenden Genesis, in der Einheit der Monade erwächst, in der die Monade ist, indem sie wird.“ (Husserl, 1973c, 37-38).

11 „Die Person, als die ,Individualität‘ einer Subjektivität, einer Monade, ist bezogen auf die Sphäre der spezifischen Aktivität in Form des ego cogito. In der Mannigfaltigkeiten dieses cogito entfaltet aber auch, entwickelt sich und wandelt sich (kehrt sich evtl. um) das eine und selbe ego als Individualität." (Husserl, 1973c, 18). 
of Intersubjectivity. First Book, 1905-1920) and from the period of Cartesian Meditations (Phenomenology of Intersubjectivity. Second Book, 1921-1928).

We will confine ourselves here to merely pointing out that Husserl, in his works of the 1920s, shifted away from the theory of empathy, which he had been elaborating until 1920 in his works collated into the first volume of Phenomenology of Intersubjectivity. In the 1920s (Phenomenology of Intersubjectivity. Second Book), the increased insight into the study of the original constitution of the living body (Leib), along with the passive synthesis which plays a part in this constitution, and which enables the fundamental unity of external and internal corporeality, was of decisive importance. In the course of these studies, Husserl shifted away from the distinction between the spheres of nature and spirit as spheres of passivity and activity, since the moment of passive constitution (passive associative synthesis) was revealed in the very constitution of subjectivity. At the same time, Husserl didn't abandon his attempts to substantiate intersubjectivity through the activity of the Self. Let us quote the explanation that Husserl gave to the theory he was elaborating at that time, the theory of empathy as the active transfer of the sense of my own living body to another body. Let us refer to the text № 34, entitled "Spatial Constitution. Questioning the 'Old' Interpretation of Empathy: Does Giving It an Explanation Require a Contradictory External Representation of My Own Movements?” (Husserl, 1973c, 520-522)12.

This text, as is evident from its title, illustrates the active work on the problem of the act of empathy, which later evolved into a theory of analogizing apperception in Cartesian Meditations. Thus, Husserl gave the following explanation for recognition of 'the Other:'

The Other, moving and actively involved in bodily functions, is given to me externally and thus, in no way from the reference point (Nullstellung). But since I consider myself being transferred [into the body of the Other], I [become aware of] the concurrence of me, as moving, and [of it] as also moving, what's more in such a way, that both moving entities are in concurrence [not just with respect to their bodily] nature. [...] But how does this lead to the transition to the investment [of the other body in the sense of my living body], which would be a contradiction? [...] It is worth asking to what extent under this [transfer] I need to verify myself with every external representation [of movement of another body], which differs from the movement of mine. Is it sufficient to refer to the analogy of [my] external movements with the functional movements of [another body] given in my perception (to that which I, broadly speaking, see)? (my translation. - N.A. $)^{13}$

12 In German: <, Raumkonstitution. Infragestellung der, alten ' Interpretation der Einfühlung: bedarf es zu ihrer Erklärung der wiedersprechenden Aussenvorstellung meiner Selbstbewegung" (wohl Februar 1927)>.

13 „Der sich bewegende, der lebendig in Leibesfunktionen betätigte Andere ist mir äusserlich gegeben, und somit zunächst nichts von Nullstellung. Aber sowie ich mich hineinversetzt denke, habe ich in eins den 
This text shows that Husserl was aware of the inadequacy of the active transfer of the sense of the Self to another body ${ }^{14}$ for the actual experience of 'the Other,' as well as the need for a more profound substantiation for the experience of 'the Other.' Husserl has discovered original inner corporeality, which represents the original psychological unity as substantiating the active transfer. In Cartesian Meditations, the place of this original unity will be taken by the initial primordial sphere, the sphere of passive executions. At this stage, the meaning of passive synthesis for constitution of 'the Other' manifests itself in the passive synthesis of association of pairing my own body, as a functional reference point, with an external body. Some texts from that period were devoted to the consideration of such passive executions ${ }^{15}$. The original associative synthesis manifests itself in the fact that my own body and the spatial body possess "the associative unity of affiliation" (Husserl, 1973c, 491), substantiated at the level of primary corporeality. This associative unity enables the passive awakening of the sense of the living body-as-flesh in relation to the external body, therefore there is no need

for an empty reference from the external to the internal [body] from without, with execution following only afterwards. They [are] both an inseparable whole and they are realized together, the internal permanently lies at the 'basis' of the external. (my translation. - N.A. $)^{16}$

In spite of the fact that Husserl was devoting the texts of this period to elaborating the theory of active recognition of 'the Other', these works also gave definition to the passive foundation, the necessity for the act of passive synthesis

äusseren Körper dort in jenen Aussenbewegungen mit mir als sich Bewegenden, und sich ebenso Bewegenden, in Deckung, und zwar so, dass die beiden Bewegungen nicht nur natural in Deckung sind. [...] Aber wie kommt es zur Setzung, die doch ein Widerspruch wäre! [...] Es fragt sich aber, ob ich es nötig habe, auf jene widersprechende Aussenvorstellung meiner Bewegung zu rekurrieren. Genügt es nicht, auf die Analogie der aüsseren Bewegungen mit Funktionsbewegungen meines Wahrnehmens (im Fernsinn, sehend) hinzuweisen?" (Husserl, 1973c, 521-522).

14 See also the app. LXVIII <,,Unmöglichkeit einer schlichten apperzeptiven Übertragung (Appresentation) leiblicher Eigenheit" (wohl Februar 1927)> (Husserl, 1973c, 496-498).

15 From Phenomenology of Intersubjectivity. Second Book: The text № 33 „Zu den alten Manuskripten: Die Gleichstellung von Nullkörper und Aussenkörper als Voraussetzung der Wirksamkeit der Analogie von Leib und Ausending“ (6. Februar 1927) (Husserl, 1973c, 510-515), as well as the text № 28 „Die einfühlende Appresentation als eine mittelbare und ihre Erfüllung" (wohl Februar 1927) (Husserl, 1973c, 488-495), app. LXXI „Einfühlung. Das Problem der Änlichkeit von Aussenkörper und Nullkörper“ (wohl Februar 1927) (Husserl, 1973c, 516-518).

16 „Ich brauche freilich nicht erst bei mir selbst einen Leerverweis von dem Aussen in das Innen und dann eine nachkommende Erfüllung. Beides ist untrennbar eins und zusammen verwirklicht, kontinuierlich liegt der Äusserlichkeit die Innerlichkeit ,zugrunde““" (Husserl, 1973c, 491). 
of association linking the living body and the spatial body into a unified, jointly realized whole. However, these texts still do not address the possibility of my own Self and 'the Other' Self (as a constitutive element of the horizon of my capabilities) being constituted jointly, although a very important reference was made to the role of passive synthesis of association for the experience of 'the Other,' responsible for the constitution of the horizon of perception. As to the possibility of interpreting the constitution of subjectivity as the co-constitution of my own and other Selves, this emerged only in the elaborations made by Husserl in his later texts.

\section{THE PROBLEM OF INTERSUBJECTIVITY IN THE "FIFTH CARTESIAN MEDITATION"}

The analysis undertaken by Husserl in the "Fifth Cartesian Meditation" was aimed at defining how the Ego can form intentionalities "of a different kind, intentionalities with an existence-sense whereby he wholly transcends his own being." (Husserl, 1960, 105).

In raising the issue of the genesis of the sense of 'the Other,' Husserl raised the question of the genesis of subjectivity itself, since for any individualized and constituted 'Self,' the 'Other' is always already there. Any activity of the individual 'Self' implies the already-present view of 'the Other.' Correspondingly, the genesis of the sense of 'the Other' must flow in a certain sphere located 'beyond' the division into subject and object (worldly) ${ }^{17}$, and since the sense of the objective world is also connected with the sense of 'the Other'18, this sphere does not belong to the time of the world either. Transcendental subjectivity, when reduced to the sphere of one's own, turns out to be anonymous, since it lies before any differentiation into subject and object. In this context, the question can be posed about the extent to which this anonymous sphere belongs to subjectivity, to consciousness. For instance, HansGeorg Gadamer believes that in that respect Husserl spoke of the following:

It is characteristic of his own intention, however, that he no longer says 'consciousness,' or even 'subjectivity,' but 'life.' He is trying to penetrate behind the actuality of the sense-giving consciousness, and even behind the potentiality of

17 Cf.: "Thus, we abstract first of all from what gives men and brutes their specific sense as, so to speak, Ego-like (ich-artige) living beings and consequently from all determinations of the phenomenal world that refer by their sense to 'others' as Ego-subjects and, accordingly, presuppose these." (Husserl, 1960, 95).

18 Cf.: "...the characteristic of belonging to the surrounding world, not merely for others who are also given at the particular time in the actual experience, but also for everyone..." (Husserl, 1960, 95). 
shared meaning, to the universality of an achievement that is alone able to measure the universality of what is achieved-i.e. (that is to say), constituted in its validity. The all-embracing world horizon is constituted by a fundamentally anonymous intentionality-i.e., not achieved by anyone by name. (Gadamer, 2004, 238)

Since the required sphere does not belong to the experience of the objective world, neither can it belong to the time of the constitution of thingness, thus the desired sphere is 'objectively' 'nowhere' and 'never.' It seems to us that this is exactly the way to understand Eugen Fink's statement declaring that initially constituting transcendental subjectivity "does not exist": "We must distinctly understand that 'transcendental being,' as a concept inverse to 'natural' or 'worldly being,' should not altogether be understood as one or another kind of being..." (my translation. N.A.) (Fink, 1988, 80-81).

However, only when the primary sphere is understood as the sphere of anonymous primary subjectivity does it become possible to consider the passive constitution of subjectivity as co-constitution.

By virtue of the "non-givenness' 19 of the sphere of primary subjectivity to me, accomplishing an abstracting reduction (dismantling analysis) in this case implies leaving the sphere of any actual experience, because discovering the desired sphere, and applying static analysis to the 'absolutely given' is evidently not possible. Therefore, in his Cartesian Meditations Husserl came to the genetic study of consciousness, revealing the desired sphere as the sphere of primary subjectivity, in which passive constitution takes place, through studying the genesis of consciousness. Thus, Husserl discovered the immanent history of consciousness as the history of primary passive synthesis.

Therefore, the sense of 'the Other' must be constituted from the primary sphere of one's own. We need to define here what is actually meant by saying that the sense of 'the Other' must be constituted 'from' the sphere of one's own: it is pure nature (primal, not one's own), not the hyletic givenness of Lectures On the Phenomenology of the Consciousness of Internal Time, nor a passive material, but the very formation of consciousness, grasped (and thus objectified) by reflection, since by genetically

${ }^{19}$ Here we can talk of non-givenness only with a certain reservation, since primary subjectivity is not an abstractly distinguished stage in the formation of the absolute subject, but a passive constitution, which, in a certain sense, is always 'given' to me, since it exerts its own constitutive influence in every act. Hereafter, we will present the interpretation of primary subjectivity as an inter-subjective field of interactions in which the individuality lives, and, in this sense, it is given to it, while at the same time it cannot become an object of reflexive study. 
distinguishing the sphere of primary subjectivity, the analysis proceeds to static description. Distinguishing the levels in the primary sphere marks the beginning of the reconstruction moving 'from' primary subjectivity along the way towards constitution of the individual Self, and not just in the sphere of one's own but, in a certain sense, it assigns the temporal self-constitution of the Ego. Let us look at a quotation illustrating the process of the passive self-constitution of subjectivity:

The ego constitutes himself for himself in, so to speak, the unity of a 'history.' We said that the constitution of the ego contains all the constitutions of all the objectivities existing for him, whether these be immanent or transcendent, ideal or real. It should now be added that the constitutive systems (systems actualizable by the Ego), by virtue of which such and such objects and categories of objects exist for him, are themselves possible only within the frame of a genesis in conformity with laws. At the same time they are bound, in their constituting, by the universal genetic form that makes the concrete ego (the monad) possible as a unity, as having particular constituents of its being that are compossible ${ }^{20}$. (Husserl, 1960, 75-76)

"Self-constitution of the Ego" is a concept with a certain ambiguity, it prompts an understanding of transcendental phenomenology as egology. However, the primary subjectivity, from which the self-constitution of the individual Self occurs, should be understood as anonymous.

In his later years, Husserl shifted away from making the distinction between passivity (merely the material) and activity (executions bearing the nature of the Self). To wit, the detectable sphere of primary subjectivity in Cartesian Meditations is passive in nature, which nonetheless does not make it hyletic material. Pure nature, 'from' which the sense of the Other must be constituted, is in this case also not merely the material 'from which' 'the Other' must be constituted. The fact that pure nature is not just the passive material is also evidenced by Husserl speaking in his Cartesian Meditations of several levels of pure nature, which in a way are superimposed on each other. Thus, for example, Husserl spoke of the phantom thing and the thing which is a substratum of causal properties as different elements in the formation of 'the body' of the sphere of one's own in the process of the coconstitution of 'the Self' in a pair with 'the other Self.'

20 „Das ego konstituiert sich für sich selbst sozusagen in der Einheit einer Geschichte, und wenn wir gesagt haben, daß in der Konstitution des ego alle Konstitutionen aller für es seienden Gegenständlichkeiten, immanenter wie transzendenter, idealer wie realer, beschlossen sind, so ist jetzt beizufügen, daß die konstitutiven Systeme, durch die für das ego die und jene Gegenstände und Gegenstandskategorien sind, selbst nur im Rahmen einer gesetzmäßigen Genesis möglich sind. Zugleich sind sie dabei gebunden durch die universale genetische Form, die das konkrete ego (die Monade) als Einheit, als in ihrem besonderen Seinsgehalt kompossibel möglich macht." (Husserl, 173a, 109). 
At this point, let us turn to the very constitution of the experience of the Other from the sphere of one's own, carried out by Husserl through detecting a body, Körper, (as the horizon of my capabilities) and a body-as-flesh (as the unity of kinesthetic syntheses) within it (in the primary sphere). 'The Other' superimposes itself as the alter Ego on a mere body, which is verified in the experience as a bodyas-flesh through analogizing apperception.

However, such constitution should not be assumed to be actual psychic analysis, i.e. as analysis located in objective temporality and sequence. Moreover, such analysis denotes an already actual ascertainment. After all, appresentation of 'the Other' is possible only if one's own body-as-flesh has been already objectified and can appear as a body-as-body (Leib-Körper). Indeed, conceiving one's own bodyas-flesh in some other place or other time (i.e. applying the exact method suggested by Husserl for verifying the alter Ego in the experience) ${ }^{21}$, means to conceive it in some certain place and time, that is, in a time which implies not only the points of here and now, but also all other possible 'heres' and 'nows,' which means to conceive it in objective time (objective and defined). However, objective time (as intersubjective time) is constitutively connected with the sense of 'the Other,' since only by verifying the other body as flesh

...the coexistence of my <polar $>$ Ego and the other Ego, of my whole concrete ego and his, my intentional life and his, my 'realities' and his-in short, a common timeform-is primally instituted; and thus every primordial temporality automatically acquires the significance of being merely an original mode of appearance of Objective temporality to a particular subject. (Husserl, 1960, 128)

Therefore, recognizing 'the Other' in experience points to the primary live ascertainment, pairing the Ego with the alter Ego, which makes it possible for 'the Other' to appear in experience. That is to say, this analogizing apperception is possible only as an anticipation (Vorweghaben) of the sense which itself only becomes verified in external experience (since, according to its sense, it cannot be verified in the sphere of one's own). The Other appears in actual experience purely through being passively anticipated. The source of primary ascertainment (passive synthesis) must always maintain 'its living presence,' since 'the Other' cannot be once-identified, due to it not being eidos for us. In the primary ascertainment, 'the Other' is designated as the direction for the subsequent constitution of the

21 "[The experience] effects this... by its identifying synthesis of the primordially given animate body of someone else and the same animate body, but appresented in other modes of appearance..." (Husserl, 1960, 128). 
intersubjective world, the Other as a characteristic of the horizon for the world to be constituted. The Other is 'always-already' designated along with the 'the Self.' The actual experience of the Other appears to be possible through the original passive synthesis of association, the primary passive constitution, to which the awakening of the passive intention (the intentional impulse) of constitution of the intersubjective world belongs. In the passively constituted empty horizon of perception, the Other is 'always-already' anticipated, therefore, when the body of the Other appears in experience, the analogizing transfer undergoes its realization, the body of 'the Other' becomes recognized as the other point of view (the view directed from another angle), 'always-already' included into the passive horizon of my perception. Further on, we will examine the act of pairing of 'the Self' and 'the other Self' as primary passive synthesis in greater detail. For now, though, we will consider the critique of the theory of intersubjectivity given in Cartesian Meditations, in order to prove that it (the critique) is erroneously based on a misinterpretation of the synthesis of pairing as an activity of consciousness. In due course, we will endeavour to demonstrate that the actual experience of the Other becomes possible only through its passive substantiation, and afterwards we will turn to an examination of the passive constitution of subjectivity as the co-constitution of 'the Self' and 'the other Self.'

\section{CRITICISM OF THE THEORY OF "ANALOGIZING APPERCEPTION" AS AN ACTIVITY OF THE SELF}

Klaus Held is numbered among the most prominent critics of Husserl's theory of intersubjectivity. In his work, "The Problem of Intersubjectivity and the Idea of Phenomenological Transcendental Philosophy," Held put forward a number of objections to the way in which the genesis of the sense of the Other was presented in Cartesian Meditations. Held believed that, since the phenomenon of the alter Ego is constituted by the analogizing transfer of my own Ego, it cannot be positional in nature, i.e. it cannot be considered as actually existing. At the same time, as Held noted, Husserl stated that the Other is clearly presented to us as actually existing. The formula "as if I were there" evidently represents a certain kind of fantasy, which cannot be considered a positional act. Held believed that at the moment when some other natural body is recognized as a living body-as-flesh similar to me, I cannot help but realize that this other natural body is merely similar to my own body (i.e. it seems to be like it), but it is not my body in reality, because my own body-as-flesh is now here and not there, it only could be there. At the same time, Held focused 
on the conditional inclination of the formula of recognition i.e. "as if I were there" („wie wenn ich dort wäre“(Held, 1972, 35)), which he saw as an inviable hybrid of two expressions, i.e. of the positional "if I am there" and the corresponding act of temporal re-presentation (reminiscence or anticipation), as well as of quasi-positional irreal "if I were there" (Held, 1972, 35), presenting my unrealized capability of now being there but not here. Held believed that the consciousness present in the act of recognition "as if I were there" should be replaced with the more accurate expression of "like if I were there" which does not conceal its surreal ideal (fantastical) nature. Based on the above, Held believed that regarding in the act of recognition we can speak only of a "fictional notion through which I'm quasi-transferring my living corporeality to There, while in reality I remain in the present (gegenwärtigen) There of my Here" (my translation. - N.A.) ${ }^{22}$.

Thus, Held came to the following conclusion:

Consciousness of the concurrence [of my own body as flesh and that of the body of the Other], which, serving as a confirmation, according to Husserl, is supposed to motivate an apperceptive overcoming of the primordial sphere, proves itself to be a quasi-positional consciousness; it leads to a quasi-duplication of my own Self, but not to the positional consciousness of the appearance of the Other... (my translation. $-N . A.)^{23}$

Held believed that analogizing apperception as a quasi-positional representation of ideal (fantastical) modifications of my own Self in the present moment (the options of my possible being at the present moment), as described by Husserl in Cartesian Meditations, and elaborated by him in his later studies of the problem of intersubjectivity, was insufficient for the interpretation of the experience of 'the Other,' which is positional in nature:

...after realization of the positional experience of the Other ... they [ideal modifications or modifications of fantasy] are revealed as necessary but insufficient conditions for the actual experience of the co-subject. (my translation. - N.A.) ${ }^{24}$

22 „...die fiktive Vorstellung, durch die ich meine Leibkörperlichkeit quasi ins Dort versetze, aber in der Realität im gegenwärtigen Dort meines Hier verharre..." (Held, 1972, 35).

23 „Das Deckungsbewusstsein, das bei Husserl die apperzeptive Überschreitung der Primordialität bewährend motivieren soll, erweist sich selbst als quasi-positionales Bewusstsein; es führt zu einer Quasi-Verdopplung meines Ich, jedoch nicht zum positionalen Bewusstsein vom Auftreten eines Mitsubjekts..." (Held, 1972, 41-42).

24 The full quote: „Die Phantasieabwandlungen meiner selbst haben aber vor und nach der positionalen Erfahrung vom Andern eine andere Bedeutung. Vorher sind sie rein primordiale Modifikationen meiner selbst, nachher erweisen sie sich als die notwendigen, aber nicht hinreichenden Bedingungen der faktischen Erfahrung vom Mitsubjekt." (Held, 1972, 43). 
In the same way, according to Held, the reconsideration ${ }^{25}$ given by Husserl to analogizing apperception, which he began to consider as a kind of re-presenting act in his later works, does not resolve the problem. As a result, Held concluded:

The failure of Husserl's theory of analogizing apperception of the co-subject (Mitsubjekt) led to the simple conclusion that none of the three types of representation can be mutually reduced to either of the others (Nicht-aufeinanderZurückführbarkeit), i.e. all of them are co-original (Gleichurpsrunglichkeit). These three types of re-presentation are: the quasi-positional primordial re-presentation (Vergegenwärtigung); the ideal (fantastical) modification (Abwandlungen) of my own Self at the present moment (mitgegenwärtigen); the positional primordial representation of modifications of my actual present into the past [present] or the future [present] and going beyond the scope of the primordial sphere the positional representation as a modification of the active (fungierenden) present into the co-present (kompräsentes) co-active present (Mitfungieren). It is the last-mentioned type of representation that was not made clear by the theory of the original apperception of the Other, but remained its prerequisite. (my translation. - N.A. $)^{26}$

According to Held, it is precisely this third type of re-presentation of the acting living present that for the first time enables a consciousness of the concurrence of my own body and the body of the Other, and at the same time makes "within certain limits valid" the theory of analogizing apperception which appeals to it (Held, 1972, 45). Held made an attempt to resolve the problem of intersubjectivity through thematization of "the living present." Since the theory proposed by Held is a theory of the "active" structuring of intersubjectivity (Held, 1972, 52), it will not be considered here.

However, it is important to note that Held's explanation of the phenomenon of intersubjectivity through the appeal to the living present is built upon the equation (which, in our view, is, at the very least, controversial) of the results of the dismantling analysis (Abbau-Analyze) of sense of 'the Other' made in Cartesian Meditations to the results of the dismantling analysis of consciousness of time to

25 Herein, Held refers to the texts of Phenomenology of Intersubjectivity. The Second Book (Husserl, 1973c) and Phenomenology of Intersubjectivity. The Third Book (Husserl, 1973d).

26 „Das Scheitern von Husserls Theorie der analogisierenden Apperzeption des Mitsubjekts führt damit zu einer einfachen Einsicht: der in die Nicht-aufeinander-Zurückführbarkeit, d.h. Gleichursprünglichkeit dreier Vergegenwärtigungsarten. Es sind dies die quasi positionale primordiale Vergegenwärtigung von mitgegenwärtigen Phantasieabwandlungen meiner selbst, die positionale primordiale Vergegenwärtigung von Abwandlungen meiner aktuellen Gegenwart in frühere oder spätere und die positionale primordialitätsüberschreitende Vergegenwärtigung als Abwandlung von fungierender Gegenwart in ein kompräsentes Mitfungieren. Genau die zuletzt genannte Vergegenwärtigungsart wird mit der Theorie der originären Apperzeption des Andern nicht erklärt, sondern bleibt vorausgesetzt.“ (Held, 1972, 44). 
the primary present, made in the later texts on the constitution of time ${ }^{27}$. In this way, the entire sphere of primary constitution was consequently reduced by Held to the sphere of the living present. Undoubtedly, both the dismantling analysis of the sense of 'the Other' and the dismantling analysis of the constitution of time result in the identification of the sphere of primary subjectivity (the primordial sphere). Of course, both cases imply an analysis which leads to distinguishing the primordial sphere as the sphere of the primary executions of consciousness, although the sphere is given (incompletely) differently in each analysis, since in each specific case the analysis is motivated by the study of the genesis of a certain aspect of cobeing in the world, i.e. in one case it can be the study of the genesis of the sense of the Other, and in the other case it is the study of the genesis of consciousness, although all these constitutions are by no means separate processes which are isolated from each other. The different stages of the structure (Stufenbau) of the primordial sphere become distinguished in the course of each of the dismantling reductions, and together they form the immanent histor ${ }^{28}$ of the constitution of the primary sphere. As for the complete sphere of primary passivity (proto-subjectivity), this becomes distinguished only through the complete abstracting reduction of every activity, not only of co-presentation to presentation (reduction of the sense of the Other) and of re-presentation to presentation (reduction of consciousness of time), but also the reduction of the activity of perception itself, of ap-presentation to presentation (reduction of perception). A description of this kind of complete reduction (of the activity the Self) is given in Husserl's "Night Talk ${ }^{29}$," published in Phenomenology of Intersubjectivity. Third Book (Husserl, 1973d, 585).

Thus, the living present represents just one of the steps in the dismantling analysis, and, therefore, it is erroneous to reduce the vast sphere of primary passivity

27 See (Husserl, 2001b, the text № 25) and (Husserl, 2006).

28 Cf. (Husserl, 2006, 395), (C.17, № 90, 1930/31): “For any dismantling reduction, there is a significant rule (Hauptsatz) stating that the levels of dismantling (Abbauschichten) don't represent something in and of themselves constituted in the genesis, in genetic sequence, which corresponds to sequence of substantiation. However, each level corresponds to a level in the genesis. Every intentionality through which the pre-given world is constituted is acquired genetically and is grasped in genetic advancement (Fortwerden). But all processes of the genesis of all layers taken together immanently temporarily substantiate, they are coexisting (koexistierende) processes of the genesis." (my translation. - N.A.).

29 The full title is: „Ein Nachtgespräch: Reduktion auf das absolute ,Ich“ des urtümlichen Strömens, das das Sein des eigenen und der anderen Ich enthält. Die Unendlichkeit von urtümlichen ego’s. Monadologie“ (22. Juni 1933). (Husserl, 1973d, 580-587). 
to the living present ${ }^{30}$. In order to support this idea, we will quote a statement made by Husserl in the text of "Night Talk":

But while I [carry on] speaking of the present, the past, of the modalities of time, I'm not reaching the last transcendental level, the one which can no longer be characterized as the flowing moment of the flowing living present. It is the original absolutely proto-flowing life of the absolute transcendental Self. (my translation. - N.A. $)^{31}$

The critique delivered by Held is a critique of the theory of empathy, understood as ap-presenting an activity of consciousness, and therefore revealing an apparent inclination towards the Ego. Held considered analogizing apperception as Husserl's attempt to substantiate the pre-themed pre-givenness of the Other through his original givenness in the experience (as of a living body) ${ }^{32}$. Among other issues, Husserl was indeed elaborating the active theory of empathy as a way to resolve the problem of intersubjectivity in some texts included in the second and third books of the Phenomenology of Intersubjectivity (the fourteenth and the fifteenth volumes of Husserliana). An attempt at an egological solution to the problem of intersubjectivity, which is (in most cases) representative of the texts from this period, makes 'the Other' a duplicate of my own Ego, depriving it of the nature of 'transcendence,' although Husserl pointed out as early as the period of Cartesian Meditations that the Other represents "the immanent transcendence" for us. However, it is important to note that the texts collected in these volumes are far from being inhomogenous, they

${ }^{30}$ Held elaborated on the topic of the living present in the book Lebendige Gegenwart. Die Frage nach der Seinsweise des transzendentalen Ich bei Husserl entwickelt an Leitfaden der Zeitproblematik (Held, 1966). In this work, he reduces the entire sphere of primary subjectivity to the real present.

31 „Aber spreche ich von Gegenwart, Vergangenheit - von Zeitmodalitäten, so bin ich noch nicht im letzten Transzendentalen, das ich nicht als strömend lebendige Gegenwart bezeichnen darf. Es ist das urtümliche, das absolut urströmende Leben des absolut transzendentalen Ich.“ (Husserl, 1973d, 583-584).

32 Although Held also spoke of the passive pre-themed grasping of the Other, he claimed that, according to Husserl, such grasping should be of active substantiation. This standpoint stemmed from the fact that Held understood passive synthesis in accordance with the division into passivity and activity of the period of Ideas. Second Book and elaborations on the intersubjectivity of the 1920s, i.e., he understood passive synthesis as being purely empirical. Within passive synthesis, Held distinguishes the secondary passivity (the former activity) and "the primary passivity", which he identified with "aesthetic passive synthesis," which in a certain way provides the proto-material for all possible apperceptive executions. Husserl determined this material as “pre-predicatively given in senses” (, ...das Urmaterial für alle möglichen apperzeptiven Vollzüge. Husserl bestimmt dieses Urmaterial als das vorpradikativ durch die Sinne Gegebene" (Held, 1972,16)). Thus, passivity appears only as a transitional moment ('not yet' or 'no longer') of activity. As a consequence of this interpretation of the correlation of passivity and activity given by Husserl, Held came to the conclusion that Husserl's passive pre-reflexive co-givenness of the Other must be substantiated by the activity of the Self. Henceforth, only active synthesis was considered by Held to be primary constitution. 
represent an elaboration of various ways of considering the theory of intersubjectivity, therefore, the above-mentioned text of "Night Talk" represents an elaboration of a standpoint which is somewhat opposite to the one which was analyzed and criticized here. Therefore, in this case, Held's presupposed understanding of transcendental phenomenology as egology is far from being correct with respect to Husserl's later texts.

\section{PASSIVE GENESIS AS A PROCESS OF CONSTITUTION OF THE EGO. THE PROTOSELF AS PRIMARY PASSIVITY}

Before focusing on considering passive synthesis as a parallel constitution of my own and other Selves, it is worth giving consideration to the soil (Urboden) which serves as the basis for the temporary proto-constitution of 'the Self,' "the absolute event of the temporalizing of transcendental subjectivity." Landgrebe noted:

By the deep dimension of primary passivity, Husserl meant the proto-original syntheses of the consciousness of time, in which the Self (das Ich) constitutes itself as temporal and comes to being conscious of itself as a flow of consciousness. (my translation. - N.A.) (Landgrebe, 1982, 72)

The passivity of this constitution is expressed in the fact that it occurs without activity on the part of the Self, because the individual Self is yet to be constituted within it. The 'standing-flowing' course of a flow, in not being the activity of the Self, is the 'source' of temporal constitution, and at the same time, being deprived of active execution, the living present of transcendental subjectivity is the passive execution.

Thus, passive genesis is the process of self-constitution of the Self, its transcendental birth, occurring at the level of non-personal primary passivity. It is important to note the ambiguity of the expression of self-constitution of the transcendental Self, for the detected sphere of primary passivity (proto-flow) is timeless and impersonal in nature. As for the former, in the course of analyzing deep layers of subjectivity, it becomes apparent that "not everything subjective is temporal" ${ }^{33}$. Primary subjectivity is the pre-temporal sphere, the process of temporal constitution (Zeitigung) 'from which' the identity of the Self emerges. We will refer to text № 43 of the $39^{\text {th }}$ volume of Husserliana, entitled “The Problem of the Beginning of (Primordial) Subjectivity. The Inceptive Affectation as the Instinctive

33 „Nicht alles Subjektive ist Zeitliches.“ (Husserl, 2001a, 277). 
One. The method of Reconstruction (to the Method of Transcendental Aesthetic Interpretation)" (Husserl, 2008, 467-484). Husserl gave the following comments on the non-temporal 'pre-being' (Vor-sein) of the Self in the aforementioned text:

The not-time (Un-zeit) of the Self, preceding the Self, temporarily constituting itself, is not infinite, uniform time that is [as yet] not occupied with 'things.' [...] Thus, nontime is the essential capability (Wesensmöglichkeit) of every Self of being endowed with time (gezeitigtsein) before the beginning of its actual time. (my translation. N.A.) (Husserl, 2008, 473)

The proto-Self, the primary subjectivity in which the temporary birth of 'the Self' (the passive genesis) occurs, is the impersonal (pre-personal) sphere. In the present instance, the usage of the term 'the Self' made by Husserl in both cases appears to be rather misleading. However, in his later texts Husserl pointed out that the proto-Self is called the "Self" only due to a certain homonymy (Husserl, 1976, 187188). In The Crisis of European Sciences and Transcendental Phenomenology, in the paragraph devoted to the proto-Self constituting the intersubjective horizon, Husserl conceded that the proto-Self came to be called the Self only as a result of homonymy. In this text, Husserl described the impersonality of the proto-Self as a fundamental 'loneliness,' which is nothing like the loneliness of Robinson ${ }^{34}$, which represents the loneliness of the individual Self (implying the possibility of other Selves). The protoSelf is lonely by virtue of there being no individuation in principle present within it.

The epoché creates a unique sort of philosophical solitude which is the fundamental methodical requirement for a truly radical philosophy. In this solitude, I am not a single individual who has somehow wilfully cut himself off from the society of mankind, perhaps even for theoretical reasons, or who was cut off by accident, as in a shipwreck, but who nevertheless knows that he still belongs to that society. I am not an ego, who still has its you, its we, its total community of cosubjects in natural validity. All of mankind, and the whole distinction and ordering of the personal pronouns, has become a phenomenon within my epoché; and so has the privilege of I-the-man among other men. The 'I' that I attain in the epoché, which would be the same as the 'ego' within a critical reinterpretation and correction of the Cartesian conception, is actually called ' $I$ ' only by equivocation-though it is an essential equivocation since, when I name it in reflection, I can say nothing other than: it is I who practises the epoché... (Husserl, 1970, 184) ${ }^{35}$

34 Although Held saw it the other way around: "At the beginning of the life of consciousness there is a transcendental Robinson.” („Am Anfang des Bewusstseinslebens steht ein transzendentaler Robinson“ (Held, 1972, 49)).

35 „Die Epoche schafft eine einzigartige philosophische Einsamkeit, die das methodische Grunderfordernis ist für eine wirklich radikale Philosophie. In dieser Einsamkeit bin ich nicht ein Einzelner, der aus irgendeinem, sei es auch theoretisch gerechtfertigten Eigensinn (oder aus Zufall, etwa als Schiffbrüchiger) sich aussondert aus der Gemeinschaft der Menschheit, der er sich aber auch dann noch zugehörig weiß. Ich bin nicht ein Ich, das 
The 'impersonal' nature of primary passivity, in which the passive constitution of the personal Self occurs, is also favoured by the fact that Husserl, when speaking of the primary stages of constitution of the personal Self in its corporeality in his later works on the phenomenology of intersubjectivity (Husserliana, the fourteenth and the fifteenth volumes XIV, XV), would write 'the self' with a small letter. In the text of "Night Talk," Husserl gave the following explanation for the impersonal nature of the proto-Self sphere of primary passivity:

The absolute Self, which in its never ceasing constancy necessarily precedes all entities, and every entity that ever can be conceived, carries "the concreteness" [of the given Self] within, preceding every concreteness, this Self is the first 'ego' of reduction, the Ego, that, in fact, should not be called so, because the alter Ego does not make sense to it. (my translation. - N.A.) ${ }^{36}$

At the same time, in raising the question of 'the source' of the constitution of 'the Self,' Husserl formulated it as a question of the genesis of "an executor of the activity of the Self" ${ }^{37}$ : "The beginning of me represents [...] the descent (Rückgang) towards the transcendental Self, and specifically to the executor of (Vollzieher) of activity" (Husserl, 2006, 348). In this respect, there is no denying that, when speaking of the proto-Self, Husserl used wordings which prompted the understanding of the proto-Self as an active principle. Even the very formulation of the question of the beginning of the self-constitution of 'the Self' is misleading. Such word usage leads one to believe that the Ego is simultaneously the author and source of every constitution, which results in transcendental phenomenology being regarded as solipsistic egology. However, designating the sphere of primary passivity as the protoSelf is mere homonymy, which is, at the same time, of important methodological significance. This homonymy indicates the Self as a researcher carrying out transcendental reduction (either in its classical sense, or in the sense of an abstracting

immer noch sein Du und sein Wir und seine Allgemeinschaft von Mitsubjekten in natürlicher Geltung hat. Die ganze Menschheit und die ganze Scheidung und Ordnung der Personalpronomina ist in meiner Epoche zum Phänomen geworden, mitsamt dem Vorzug des Ich-Mensch unter anderen Menschen. Das Ich, das ich in der Epoche erreiche, dasselbe, das in der kritischen Umdeutung und Verbesserung der Descartes'schen Konzeption das ,ego' wäre, heißt eigentlich nur durch Äquivokation ,Ich,' obschon es eine wesensmäßige Äquivokation ist, da, wenn ich es reflektierend benenne, ich nicht anders sagen kann als: ich bin es, ich der Epoche-Übende..." (Husserl, 1976, 187-188).

36 „Das absolute Ich, das in nie zerbrechlicher Ständigkeit vor allem Seienden ist und alles Seiende in sich trägt, in seiner ,Konkretion' vor allen Konkretionen, das alles und jedes erdenkliche Seiende in sich tragende, ist das erste ,ego' der Reduktion - ein ego, das fälschlich darum so heisst, weil für es ein alter ego keinen Sinn gibt.“" (Husserl, 1973d, 586).

37 Cf. (Husserl, 2001a, № 14, № 15), as well as text № 43 (Husserl, 2008). 
reduction of genetic phenomenology). Such a reminder that this 'Self' is currently performing epoché cannot be superfluous. Indeed, it is precisely the fact that the primary subjectivity, "the proto-flowing Self" (urströmende Ich), becomes revealed in the course of phenomenological research that makes this absolute transcendental subjectivity phenomenologically significant. It is precisely the fact that this realm is discovered through research which prevents transcendental subjectivity from being an empty abstraction or a metaphysical prerequisite to classical philosophy. It was exactly this transcendental subjectivity (the infinite proto-flow of experiences ${ }^{38}$ ) which Husserl described as flowing even before we are born and continuing when we die, even though the individual Self is certainly defined by 'birth' and 'death':

...we have the right to believe that birth is the beginning of life (the life of consciousness), which however must have [its] before (ein Vorher), an earlier time which yet remains unknown, unrecognized, unremembered to a human being, who exists from birth. A similar statement [is true] for death. (my translation. - N.A.) (Husserl, 2006, 424)

Transcendental subjectivity, being only the pre-existence for the individual Self, is revealed at the same time as a condition for the possibility of its 'awakening:' "But 'the being' of the Self in non-temporality means that 'the beginning' already assumes the Self as [that] which may be awakened to a temporal life." (Husserl, 2008,474 ). The constitution of the personal 'Self' does not begin out of nothing, it occurs in the sphere of primary passivity (the original subjectivity), in the protoflowing Self, and includes the possible horizons for both the Self and the other Self. A child who has just appeared in the world, and who has yet to be constituted as a Self, is already included into subjectivity, moreover even before its birth it already has expectations etc. placed upon it.

When understood in this way, primary subjectivity is historical ${ }^{39}$, it represents the endless linkage (system) of experiences and influences (like Dilthey's Erlebniszusammenhang). Transcendental (monadic, in the sense used by Leibniz) subjectivity can be understood, in this case, as the linkage of separate personal Selves

38 Cf. “To be exact, the infinite flow doesn't have the beginning..." (my translation. - N.A.) (Husserl, 2008, 472).

39 Ludwig Landgrebe, Husserl's student and a continuer of his ideas, considered the self-interpretation of transcendental subjectivity as experience (Erleben) and transcendental subjectivity itself as the interrelation of experiences (Erlebnisszusammenhang), i.e. as subjectivity with a common history, in his book The Concept of the Experience, which was also his doctoral thesis. Working on this paper, Landgrebe referred to Wilhelm Dilthey's term of Erlebnisszusammenhang and to Martin Heidegger's project of fundamental ontology (Landgrebe, 2010). 
(monads), which are linked with each other by the relation of their influence (on each other). This primary subjectivity should be distinguished from my own temporary personal being in the world, since it is a necessary condition for such being, a condition which is revealed during reduction. In The Sixth Cartesian Meditation, Fink gave the following explicit expression of the essence of transcendental subjectivity when contemplated in this way:

Does the transcendental time of the constitution of the world possess a 'beginning' corresponding to the worldly birth and a transcendental 'end', corresponding to the worldly death, in the same way that the time of a human being, which originates in the world and ends with death, does? Or do 'birth' and 'death' merely constitute sense formations in the reductively given transcendental life, and the human beginning presupposes an already extant transcendental existence, which makes itself worldly (verweltlicht) in a human being, and which must constitute its own worldly origin and also, probably, its death in the world, not being as a human being, presupposes the existence of a transcendental subjectivity which constitutes 'death' in the withdrawal of itself (einem Sich Zurückziehen) from worldly self-objectification. (my translation. N.A.) (Fink, 1988, 68)

So my individuality becomes constituted in primary subjectivity, it becomes constituted bodily (Verleiblichung) in the world (Verweltlichung), and thereby the transcendental subject becomes individualized. However, bodily constitution in the world on its own is not sufficient for the constitution of the personal Self. Thus, in text № 17 of the Phenomenology of Intersubjectivity. Third Book, entitled "My Primordial Being as of a 'Human Being' and Its Transcendental Constitution. The Problem of Separation of the Self and the Non-Self and the Living Body. The Possibility of the Non-worldly Self in Primordiality” („Mein primordiales Sein als ,Mensch“ und seine transzendentale Konstitution. Das Problem der Scheidung von Ich und Nicht-Ich und der Leib. Die Möglichkeit eines Nichtweltlichen Ich in der Primordialität") Husserl pointed out that the worldly (verweltliche) constitution is by itself not sufficient for the constitution of the individual Self, as a human being, for such constitution also requires another passively flowing synthesis. Let us look at this quote:

Must we not affirm [the following]: the proto-being is the totally flowing absolute life ${ }^{40}$, in which correlative synthesis occurs, the synthesis which constitutes the Self (a constitution, which has a completely different meaning from the constitution of the world [occurring] gradually (in Stufen), which becomes realized through phenomena),

${ }^{40}$ Husserl also spoke of the proto-Self as the life of transcendental subjectivity in "Manuscripts of C-Group" (Husserl, 2006). 
on the other hand, it is exactly this ontifying constitution [which is present], and, respectively, synthesis? (my translation. - N.A. $)^{41}$

So at the level of primordial passivity along with ontifying synthesis, there is also another synthesis occurring, one that ensures the constitution of the Self.

In summary: as a result of the dismantling analysis, research reveals the impersonal sphere of primary passivity, which Husserl designated as the Self (or the Proto-Self) only by virtue of a certain homonymy, a homonymy which is nonetheless of important methodological significance, because transcendental subjectivity is thereby granted the authentic nature of the Proto-being (Ursein) of consciousness. Concretization of the sphere of one's own, the bodily constitution and individualization of the Self, occurs 'from' primary passivity as from the 'primary ground' (Urboden). The personal Self which is to be constituted discovers its connection with the Other as the horizon of possible being in the world. It also becomes apparent that worldly constitution is insufficient for the constitution of the individual Self (for its individuation) from the essentially impersonal, primordial sphere, and that there is also a requirement for a passive constitution which functionally 'integrates' the Self into the world. On the other hand, 'the Other,' as the possibility of another view, is included in the empty horizon of perception, it appears to be pre-given to the Self and, therefore, is a result of passive constitution.

\section{PASSIVE GENESIS AS A PROCESS \\ OF CO-CONSTITUTION OF THE SELF \\ AND THE OTHER SELF}

As has been established above, constitution occurs at an anonymous prereflexive level, and hence the constitution of the other Self also occurs at a prereflexive level ${ }^{42}$, since the individual, personal Self which is subject to constitution is inconceivable outside the intersubjective horizon. In this way, passive synthesis should be revealed not only as the genesis of the individual Ego, but also as the genesis of the alter Ego. Both the alter Ego and the Ego are constituted in primary passivity, which becomes revealed as impersonal subjectivity. As previously

41 „Müssen wir nicht sagen: Das Ursein ist das total strömende absolute Leben, im dem notwendig eine korrelative Synthesis waltet, die Synthesis, welche das Ich konstituiert (eine Konstitution, die einen total anderen Sinn hat als die in Stufen < geschehende> Weltkonstitution, die durch Erscheinungen leistet), andererseits eben diese, die ontifizierende Konstitution, bzw. Synthesis?“" (Husserl, 1973d, 287).

42 On the pre-reflective level as the level of constitution of intersubjectivity see (Iribarne, 1994, 178). 
mentioned, Husserl identifies in the Cartesian Meditations the possibility of the parallel passive constitution of mine and other Selves as an act of pairing. Additionally, the possibility of the parallel constitution of my own and other Selves was considered in Husserl's later texts (e.g. the aforementioned "Night Talk").

In his book Edmund Husserl on Passive Synthesis and Intersubjectivity, Ichiro Yamaguchi, a Japanese researcher of Husserl's phenomenology, points to the possibility for the act of pairing to be understood as the passive execution of consciousness. In this way, Yamaguchi believed that "the appresentation, which forms a pair, initially acts in the living present, in the present field of perception, but not in identification of the Self's nature, which belongs to an already higher level" (Yamaguchi, 1982, 125). Yamaguchi saw the impersonal sphere of primary subjectivity, in which the passive co-constitution of the 'the Self' and 'the other Self' occurs, as the sphere of primary interaction (Mitleben), in which the Self participates without 'Self-Reflection.' In elaborating the theory of the mutual (wechselseitig) constitution of my own and other Selves in the course of non-reflexive I-You-acts, Yamaguchi in the main continued the ideas of his teacher, Bernhard Waldenfels (Waldenfels, 1971).

Let us therefore return to the consideration given by Husserl to the act of pairing. In Cartesian Meditations, Husserl determined the act of pairing as the most essential basis for the experience of the Other, since "ego and alter ego are always and necessarily given in an original 'pairing'" (Husserl, 1960, 112) ${ }^{43}$. The act of "pairing" "is a primal form of that passive synthesis which we designate as 'association,' in contrast to passive synthesis of 'identification' "(Husserl, 1960, $112)^{44}$, and is also a universal phenomenon of the transcendental (and, at the same time, the intentional and psychological) sphere. The act of pairing as the primary passive ascertainment of subjectivity passively exerts its "living influence" upon every act of the Self:

...we may add forthwith, as far as a pairing is actually present, so far extends that remarkable kind of primal instituting of an analogizing apprehension-its continuous primal institution in living actuality-which we have already stressed as the first peculiarity of experiencing someone else. Hence it is not exclusively peculiar to this experience. (Husserl, 1960, 112) ${ }^{45}$

43 „...ego und alter ego immerzu und notwendig in ursprünglicher Paarung gegeben sind.“ (Husserl, 1973a, 142).

44 „...Paarung [...] ist eine Urform derjenigen passiven Synthesis, die wir gegenüber der passiven Synthesis der Identifikation als Assoziation bezeichnen." (Husserl, 1973a, 142).

45 „...um es gleich beizufügen, so weit eine Paarung aktuell ist, so weit reicht jene merkwürdige Art in lebendiger Aktualität verbleibender Urstiftung einer analogisierenden Auffassung, die wir als jene erste Eigentümlichkeit 
In considering the act of pairing as the basis for the experience of 'the Other', Husserl reasoned as follows: during the dismantling analysis of the sphere of primary subjectivity, 'in' which the individual Self is constituted, a descriptive (static) definition of the distinguished sphere is given. Hereafter, the stages of the genesis of the individualized Self become reconstructed through inverse questioning, going from formed sense, in this case from the fully-fledged personal monadic Self, to its genesis. The process of individualization, the constitution of the Self, becomes revealed as a process of bodily constitution. The Self becomes constituted as that which has a body, i.e. from the impersonal bodily unity of functions of the firstorder sphere to the bodily inclusiveness into the intersubjective world. At the same time, the living body is constituted (like anything else which is constituted) in a pair with the possible Other, however it as not a duplication of itself, since this coconstitution is passive, and it should not be called 'my' synthesis of association. In this way, the already constituted actual Self is pre-given with the sense of 'the Other', it is passively awakened according to the law of association (motivation), when 'the Other' enters my experience, and as a result, 'the Other' appears to be given to me in experience through the analogizing transfer of the pre-given sense, motivated according to the law of association.

The Other is thus perceived neither through reproduction, nor through fantasy, i.e. the perception of the Other is neither a fantasy nor a temporal modification. The formula "as if I were there" does not mean, as Held put it in his critique of intersubjectivity theory, a mixture of ideal (fantastical) consciousness and the consciousness of temporal modification (memory ${ }^{46}$ and anticipation). As we have noted above, elaborating his critique of the theory of intersubjectivity of Cartesian Meditations, Held understood the act of pairing as an activity of the Self, and yet he did not take into consideration the passive nature of this execution. The formula "as if I were there" expresses the view of the Other being included into my perception ${ }^{47}$, as

der Fremderfahrung hervorgehoben haben, die somit nicht ihr ausschließlich Eigentümliches ausmacht.“ (Husserl, 1973a, 142).

46 As we have noted above, in elaborating his critique of the theory of intersubjectivity of Cartesian Meditations Held understood the act of pairing as an of activity of the Self, without taking into consideration the passive nature of this execution.

47 Cf. the text № 33 which dates from the period when Husserl was working on Cartesian Meditations (Phenomenology of Intersubjectivity. The Second Book, 1927): “The kinaestheses indicate the bodily movement and it, in turn, indicates the kinaestheses. But such an indication is always executed in the original perception, at the same time, disclosing the horizon back and forth.” (my translation. - N.A.). „Die Kinästhesen indizieren die körperliche Bewegung, und diese wieder die Kinästhesen. Aber diese Indikation ist immer 
the horizon of my capabilities. 'The Other' appears in perception simultaneously with the other's body, similar to mine, nor are we dealing with two different perceptions, but with a single one, there is no such pause between them as with reminiscences. The Other appears to be given to me in experience via the analogizing transfer of the sense of the primary bodily subjectivity, passively motivated according to the law of association ${ }^{48}$. It becomes possible only because my own Self is being constituted in a pair with the Other, as my capability of being different, which results in 'the Other', as the capability of another view, being always-already included in the horizon of perception, in this sense 'the Other' is always-already expected (passive intention) and, thereafter, it can itself be perceived in actual experience.

It is obvious that the synthesis of association of which we are speaking should be understood not as an empirical synthesis, but as a transcendental law of subjectivity, representing the internal passive motivation for the constitution of subjectivity within the intersubjective horizon. Such a motivation represents passive intentionality, the intentionality of an impulse (Triebintentionalität) being awakened by primary passive synthesis.

It should be noted that primary passive synthesis assigns a certain nature to the horizon which is to be constituted, a certain direction and "attunedness" awakening of the passive intentional impulse (Triebintentionalität) belongs to passive constitution in the primary subjectivity, to the transcendental birth of the Self. The primary productive passive synthesis (in passive constitution) awakens the "subject

erfühlt in ursprünglicher Perzeption, zugleich horizontmässig vorweisend und zurückweisend.“ (Hussel, 1973c, 511).

48 Cf. the text № 35 which belongs to the period of Husserl’s work on Cartesian Meditations (Phenomenology of Intersubjectivity. The Second Book, 1927): "But how we should understand: as if I were there? Here we are dealing with an open (offenliegende) association, directly demonstrable as an intentional phenomenon." (my translation. - N.A.). „Aber nun, wie ist jenes , als ob ich da hineingestreckt wäre zu verstehen? Wir haben hier eine offenliegende Assoziation, eine direkt aufweisbare als intentionales Phänomen." (Hussel, 1973c, 529).

49 It seems to us that it is entirely appropriate to compare passive intentionality and the passive horizon, as they are understood here, with Heidegger's concept of "Being-attuned" (being in a mood) (Gestimmtsein). This parallel certainly requires further study, and is mentioned here only in passing. It should be noted that such an elaboration of passive synthesis as forming the horizon is presented in Ludwig Landgrebe's Der Begriff des Erlebens. Ein Beitrag zur Kritik unseres Selbstverständnisses und zum Problem der seelischen Ganzheit. Landgrebe devotes an entire chapter, entitled "Formation of the Horizon (Horizontbildung) and Passivity," of the work to this topic. Let us look at a quotation illustrating the thoughts of the author: "The associative awakening itself must be understood as a structure for the formation of a horizon. [...] The problem of Being-attuned (being in a mood) is nothing more than the very problem of the formation of a horizon, which means that we face the task of disclosing those structures that for the first time allow the world to be a horizon." (my translation. - N.A.) (Landgrebe, 2010, 127-128). 
of the impulse" ${ }^{50}$ or, rather, its impulse towards the bodily constitution of itself in the intersubjective world awakens. 'The whole' of passive constitution occurs in the direction assigned in the awakened intentional impulse.

At this point, having established the role of passive synthesis in the constitution of subjectivity as an act of pairing (that is, having established the constitution of the Self as co-constitution), we can conclude that the primary passive synthesis which assigns the primary passive constitution of subjectivity as a process of constitution of the individual Self in a pair with the other Self, awakens intent towards the constitution of the intersubjective world, as well as determining the constitution of the intersubjective horizon of the world. This interpretation of Husserl's later works could, to some degree, be proved correct by considering intersubjectivity as it is described in manuscript № 34 of Phenomenology of Intersubjectivity. Third Book (1933), entitled "Universal Theology. Transcendental Animation of the Intersubjective Impulse, Spanning All and Every Subject. The Being of Monadic Totality"51. Here Husserl stated that, in respect of any active fulfillment of the Self, we must

...presuppose the universal intentionality, which determines the unity of every primordial present as stationary, temporalizing, and concretely leading from [one] present to [the Other] present in such way that the content intended to every content is the content of the execution of the impulse and pursuing the aim, and moreover in such a way that, in the primordial present, the transcending impulses of a higher level reach every other present and connect [them] all with each other as monads, due to all of [them] implicitly containing the Other [in such] intentional manner. (my translation. - N.A. $)^{52}$

As can be seen from this quote, Husserl considered the passive intentional impulse to be the basis for constructing intersubjectivity.

50 Cf. "When we understand an association as an association of impulses, we are dealing not with an empty association of 'ideas', but with an association of designated impulses and directed movements of impulses (Triebläufe), passive pursuits (Strebenläufen) and their immanent influences. Such an execution awakens not an empty idea, but the Self as the subject of an impulse and one's own impulse itself." Transcr. AVII 13, S. 20a (1921). (my translation. - N.A.) (Yamaguchi, 1982, 57).

${ }^{51}$ Nr. 34. „Universale Teleologie. Der intersubjektive, alle und jede Subjekte umspannende Trieb transzendental gesehen. Sein der monadischen Totalität“ (Schluchsee, September 1933) (Hussel, 1973d, 593-597).

52 „Dürfen oder müssen wir nicht eine universale Triebintentionalität voraussetzen, die jede urtümliche Gegenwart als stehende Zeitigung einheitlich ausmacht und konkret von Gegenwart zu Gegenwart forttreibt derart, dass aller Inhalt Inhalt von Trieberfüllung ist und vor dem Ziel intendiert ist, und dabei auch so, dass in jeder primordialen Gegenwart transzendierenden Triebe höherer Stufe in jede andere Gegenwart hineinreichen und alle miteinander als Monaden verbinden, während alle ineinander impliziert sind - intentional?" (Hussel, 1973d, 595). 
However, the sphere of primary subjectivity (the proto-Self) which is achieved as a result of the dismantling analysis, as the beginning of passive constitution (the transcendental birth of the Self), is not an empty abstraction. It is in the sphere of primary subjectivity that the passive awakening of passive intention occurs, directing the bodily constitution of the individual Self in the world as coexisting with other Selves. Thus, the same issue of constitution can be considered from the aspect of its actual realization of the individual history of a human being. Therefore, we are speaking not of two separate processes, but of a single process at two different descriptive levels.

\section{CONCLUSION}

We began by putting forward the hypothesis that it was precisely the demand for thematisation of the genesis of the sense of 'the Other' which largely influenced the modification of the phenomenological method. The dismantling analysis of genetic phenomenology, disclosing the sphere of primary passive constitution, 'in which' the individual 'Self' becomes constituted, is motivated by the problem of intersubjectivity. In this way, Husserl sought to solve the problem of intersubjectivity through revealing the possibility of the genesis of the individual 'Self' (as occurring in a pair with 'the Other'). Certain texts from Phenomenology of Intersubjectivity (the First and the Second Books) indicated that in the 1920s Husserl, while attempting to solve the problem of intersubjectivity, turned his thoughts to considering the genesis of the individual monadic Self. During this period, Husserl was endeavouring to resolve the problem of intersubjectivity through structuring monadology, going from an individual monad to a community of monads. However, the individual Self, as a monad, and its genesis were still linked by Husserl to the activity of the Self, which resulted in the egocentric theory of intersubjectivity being elaborated in his works on intersubjectivity from the period, both prior to the Cartesian Meditations (Phenomenology of Intersubjectivity. First Book, 1905-1920) and during the period of Cartesian Meditations (Phenomenology of Intersubjectivity. Second Book, 1921-1928). Structuring intersubjectivity on such a basis proved to be highly problematical, and as a result the very correlation between activity and passivity came to be reconsidered over the course of the elaboration of the problem of intersubjectivity. In this way, the study of the genesis of an individual monad opened the way for the thematisation of primary passivity, since only if the individual Self, along with all its own activities, has its own genesis and, hence, its beginning, 
its own transcendental birth, can passivity be understood as primary in relation to the activity of the Self. Only by considering the individual Self as having his own genesis can we refer to a primary passive constitution. Notwithstanding the fact that Husserl was devoting the texts of this period to developing the theory of the active recognition of 'the Other,' these works also point to the passive foundation, the demand for the act of passive synthesis of association, which links the living body and the spatial body into a jointly realized whole. However, in these texts there is still no mention of the possibility of my own Self and 'the other' Self (as a constitutive element of the horizon of my capabilities) being constituted jointly, although very important reference was made to the role of passive synthesis of association for the experience of 'the Other,' which is responsible for the constitution of the horizon of perception. As for the possibility of interpreting the constitution of subjectivity as the co-constitution of my own Self and the other Self, this emerged only in elaborations made in Husserl's later texts.

Our examination of the "Fifth Cartesian Meditation" demonstrated that the actual experience of the Other appears to be possible through original passive synthesis of association, the primary passive constitution, to which the awakening of the passive intention (the intentional impulse) of constitution of the intersubjective world belongs. In the passively constituted empty horizon of perception, the Other is "always-already" anticipated, therefore, when the body of the Other appears in the experience, the analogizing transfer undergoes its realization, the body of 'the Other' is recognized as the other point of view (the view directed from another angle, "always-already" included into the passive horizon of my perception. The act of pairing of 'the Self' and 'the other Self' must be understood as the primary passive synthesis.

We then examined the critique of the theory of intersubjectivity in Cartesian Meditations. In the course of this consideration, we discovered that the critique was based on an erroneous (in our view) interpretation of the synthesis of pairing, seeing it as the activity of consciousness, which in turn was based on a specific interpretation conferred by Held onto passivity and activity. Such a standpoint stemmed from the fact that Held understood passive synthesis in accordance with a distinction made between passivity and activity indicative of the period of Ideas. Second Book, and works on intersubjectivity from the 1920s, i.e. he understood passive synthesis as purely empirical. Held equated "primary passivity" with "aesthetic passive synthesis," therefore passivity appears only as a transitional moment ("not yet" or "no longer") 
of activity. As a result of this interpretation of the correlation between passivity and activity given by Husserl, Held came to the conclusion that Husserl's passive prereflexive co-givenness of the Other must be substantiated by activity of the Self, and consequently only active synthesis was understood as primary constitution. The entire sphere of primary passivity is reduced by Held to the living present. However, the reduction of primary subjectivity to the living present is erroneous, since the dismantling analysis of Time-Consciousness to the living present represents just one kind of dismantling analysis. As for the complete sphere of primary passivity (proto-subjectivity), it becomes distinguished only through the complete abstracting reduction of every activity, not just of co-presentation to presentation (the reduction of the sense of the Other) and re-presentation to presentation (the reduction of the consciousness of time), but also the reduction of the activity of perception itself, of ap-presentation to presentation (the reduction of perception).

From there we turned to the concept of primary subjectivity. Primary subjectivity is revealed to be the ground (Urboden) on which the temporary protoconstitution of 'the Self' takes place, "the absolute event of the temporalizing of transcendental subjectivity." Primary subjectivity, the pre-being of the Self, is not just a deeper level of the individual Ego, nor is it the absolute subjectivity of classical metaphysics. The sphere of primary passivity is designated as the Self by virtue of a methodologically significant homonymy. This homonymy indicates the Self as a researcher performing transcendental reduction (either in its classical sense or in the sense of the abstracting reduction of genetic phenomenology). Such a reminder that this 'Self' is currently performing epoché cannot be superfluous. Indeed, it is precisely the fact that the primary subjectivity, "the proto-flowing Self" (urströmende Ich), is revealed in the course of phenomenological research that makes this absolute transcendental subjectivity phenomenologically significant. It is precisely the fact that this realm comes to be discovered through research that makes transcendental subjectivity neither an empty abstraction, nor a metaphysical prerequisite. It is in the sphere of primary subjectivity that the passive awakening of passive intention occurs, directing the bodily constitution of the individual Self in the world as coexisting with other Selves. Primary passive synthesis was revealed as an awakening of the passive intentionality of the individual Self to the co-constitution of the intersubjective world.

As to the problem of intersubjectivity, only a deepening of the analysis of the passive sphere, and the change in methodology required for it, allow us to avoid egocentrism and to resolve the problem of intersubjectivity. We then showed that the identification of the proto-Self must be understood as being methodologically 
significant for the substantiation of intersubjectivity, since only in its 'context' does the ultimate level of the foundation of the individual Self appear to be not merely a deeper level of consciousness, or the history of a universal subject, but the absolute subjectivity, as a field of intersubjective interaction in which the individual subject is awakened (individualized) to self-constitution in the world. Only then can we reconsider the constitution of the individual Self as being primarily passive, as being permeated by the primordial passive, independent from the Self, aiming for the coconstitution of the intersubjective world.

\section{REFERENCES}

Alloa, E., Bedorf, T., Grüny, G., \& Klass, T.N. (Eds.). (2012). Leiblichkeit. Begriff, Geschichte und Aktualität eines Konzepts. Tübingen: Mohr Siebeck/UTB.

Borisov, E. (1999). Problema intersub'ektivnosti v fenomenologii E. Gusserlja [The Problem of Intersubjectivity in Fenomenology of E. Husserl]. Logos, 1(11), 65-83. (in Russian).

Fink, E. (1988). VI. Cartesianische Meditation. Husserliana, Dokumente, Bd.2/1. Dordrecht: Kluwer.

Fuchs, T. (2008). Leib und Lebenswelt. Neue philosophisch-psychiatrische Essays. Kusterdingen: Die Graue Edition.

Fuchs, T. (2010). Das Gehirn - ein Beziehungsorgan. Eine phänomenologisch-ökologische Konzeption. Stuttgart: Kohlhammer.

Gadamer, H.-G. (2004). Truth and Method. London, New York: Continuum Publishing Group.

Gallagher, Sh. (2012). Kognitionswissenschaften - Leiblichkeit und Embodiment. In E. Alloa, T. Bedorf, C. Grüny, \& T. Klass (Eds.), Leiblichkeit. Begriff, Geschichte und Aktualität eines Konzepts (320-333). Tübingen: Mohr Siebeck/UTB.

Held, K. (1966). Lebendige Gegenwart. Die Frage nach der Seinsweise des transzendentalen Ich bei Husserl entwickelt an Leitfaden der Zeitproblematik. Den Haag: M. Nijhoff.

Held, K. (1972). Das Problem der Intersubjektivität und die Idee einer Phänomenologischen Transzendentalphilosophie. In U. Claesges \& K. Held (Eds.), Perspektiven transzendentalphänomenologischer Forschung (3-60). Dordrecht: Springer.

Husserl, E. (1950). Ideen zu einer reinen Phänomenologie und phänomenologischen Philosophie. Erstes Buch: Allgemeine Einführung in die reine Phänomenologie (Hua III). Den Haag: M. Nijhoff.

Husserl, E. (1952). Phänomenologische Untersuchungen zur Konstitution (Hua IV). Den Haag: M. Nijhoff.

Husserl, E. (1959). Erste Philosophie (1923/24). Zweiter Teil: Theorie der phänomenologischen Reduktion (Hua VIII). Den Haag: M. Nijhoff.

Husserl, E. (1960). Cartesian Meditations. An Introduction to Phenomenology. Dordrecht: Springer Science+Business Media.

Husserl, E. (1966). Analysen zur passiven Synthesis. Aus Vorlesungs- und Forschungsmanuskripten 1918-1926 (Hua XI). Den Haag: M. Nijhoff.

Husserl, E. (1970) The Crisis of European Sciences and Transcendental Phenomenology. An Introduction to Phenomenological Philosophy. Northwestern University Press.

Husserl, E. (1973a). Cartesianische Meditationen und Pariser Vorträge (Hua I). Den Haag: M. Nijhoff. Husserl, E. (1973b). Zur Phänomenologie der Intersubjektivität. Texte aus dem Nachlass. Erster Teil. 1905-1920 (Hua XIII). Den Haag: M. Nijhof. 
Hussel, E. (1973c). Zur Phänomenologie der Intersubjektivität. Texte aus dem Nachlass. Zweiter Teil. 1921-1928 (Hua, XIV). Den Haag: M. Nijhoff.

Husserl, E. (1973d). Zur Phänomenologie der Intersubjektivität. Texte aus dem Nachlass. Dritter Teil. 1929-35 (Hua XV). Den Haag: M. Nijhof.

Husserl, E. (1976). Krisis der europäischen Wissenschaften und die transzendentale Phänomenologie. Eine Einleitung in die phänomenologishe Philosophie (Hua VI). Den Haag: M. Nijhoff.

Husserl, E. (2001). Zur phänomenologischen Reduktion. Texte aus dem Nachlass (1926-1935) (Hua XXXIV). Dordrecht: Kluwer Academic Publishers.

Husserl, E. (2001a). Die Bernauer Manuskripte über Zeitbewusstsein (1917/1918) (Hua XXXIII). Dordrecht: Springer Science+Business Media.

Husserl, E. (2006). Späte Texte über Zeitkonstitution (1923-1924): Die C. Manuskripte. Husserliana: Materialien VIII. Dordrecht: Springer.

Husserl, E. (2008). Die Lebenswelt. Auslegungen der vorgegebenen Welt und ihrer Konstitution. Texte aus dem Nachlass (1916-1937) (Hua XXXIX). New York: Springer.

Iribarne, J. V. (1994). Husserls Theorie der Intersubjektivität. Freiburg in Br. - München.

Landgrebe, L. (1982). Das Problem der passiven Konstitution. In Faktizität und Individuation. Studien zu den Grundfragen der Phänomenologie (71-87). Hamburg: Meiner.

Landgrebe, L. (2010). Der Begriff des Erlebens. Ein Beitrag zur Kritik unseres Selbstverständnisses und zum Problem der seelischen Ganzheit. Würzberg: Königshausen \& Neumann.

Novotny, K. (2012). Neue Konzepte der Phänomenalität. Essays zur Subjektivität und Leblickeit des Erscheinens. Würzburg: Königshausen \& Neumann.

Waldenfels, B. (1971). Das Zwischenreich des Dialogs. Sozialphilosophische Untersuchungen in Anschluß an E. Husserl. Den Haag: M. Nijhoff.

Yamaguchi, I. (1982). Passive Synthesis und Intersubjektivität bei Husserl. Hague: M. Nijhoff. 